\title{
INSTRUMENTATION FOR AUTOMATIC CYCLING OF LITHIUM-ALUMINUM/IRON SULFIDE SECONDARY CELLS by
}

W. F. Olsen and M. A. Slawecki

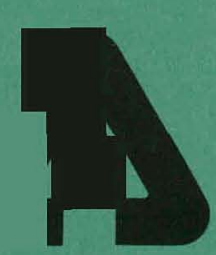

UOFC-AUA-USEROA

ARGONNE NATIONAL LABORATORY, ARGONNE, ILLINOIS Prepared for the U. S. ENERGY RESEARCH AND DEVELOPMENT ADMINISTRATION under Contract W-31-109-Eng-38 


\section{DISCLAIMER}

This report was prepared as an account of work sponsored by an agency of the United States Government. Neither the United States Government nor any agency Thereof, nor any of their employees, makes any warranty, express or implied, or assumes any legal liability or responsibility for the accuracy, completeness, or usefulness of any information, apparatus, product, or process disclosed, or represents that its use would not infringe privately owned rights. Reference herein to any specific commercial product, process, or service by trade name, trademark, manufacturer, or otherwise does not necessarily constitute or imply its endorsement, recommendation, or favoring by the United States Government or any agency thereof. The views and opinions of authors expressed herein do not necessarily state or reflect those of the United States Government or any agency thereof. 


\section{DISCLAIMER}

Portions of this document may be illegible in electronic image products. Images are produced from the best available original document. 
The facilities of Argonne National Laboratory are owned by the United States Government. Under the terms of a contract (W-31-109-Eng-38) between the U. S. Energy Research and Development Administration, Argonne Universities Association and The University of Chicago, the University employs the staff and operates the Laboratory in accordance with policies and programs formulated, approved and reviewed by the Association.

\section{MEMBERS OF ARGONNE UNIVERSITIES ASSOCIATION}

The University of Arizona Carnegie-Mellon University Case Western Reserve University

The University of Chicago

University of Cincinnati

Illinois Institute of Technology

University of Illinois

Indiana University

Iowa State University

The University of Iowa
Kansas State University The University of Kansas

Loyola University Marquette University Michigan State University The University of Michigan University of Minnesota Universily of Missouri Northwestern University University of Notre Dame
The Ohio State University

Ohio University

The Pennsylvania State University

Purdue University

Saint Louis University

Southern Illinois University

The University of Texas at Austin Washington University

Wayne State University

The University of Wisconsin

\section{NOTICE}

This report was prepared as an account of work sponsored by the United States Government. Neither the United States nor the United States Energy Research and Development Administration, nor any of their employees, nor any of their contractors, subcontractors, or their employees, makes any warranty, express or implied, or assumes any legal liabilityor responsibility for the accuracy, completeness or usefulness of any information, apparatus, product or process disclosed, or represents that its use would not infringe privately-owned rights. Mention of commercial products, their manufacturers, or their suppliers in this publication does not imply or connote approval or disapproval of the product by Argonne National Laboratory or the U. S. Energy Research and Development Administration.

Printed in the United States of America

Available from

National Technical Information Service

U. S. Department of Commerce 5285 Port Royal Road

Springfield, Virginia 22161

Price: Printed Copy $\$ 3.50$; Microfiche $\$ 3.00$ 
Distribution Category:

Energy Storage--E1ectrochemica1 (UC-94c)

ANL-76-119

ARGONNE NATIONAL LABORATORY

9700 South Cass Avenue

Argonne, Illinois 60439

INSTRUMENTATION FOR AUTOMATIC CYCLING OF

LITHIUM-ALUMINUM/IRON SULFIDE SECONDARY CELLS

(N)

by

W. F. O1sen and M. A. S1awecki

Chemical Engineering Division Research and Development Administration, nor any of their employees, nor any of their contractors, warranty, express their employees, makes any liability oxpress or implied, or assumes any legal or usefulness of any informetion, accuracy, completeness 
THIS PAGE

\section{WAS INTENTIONALLY LEFT BLANK}


ABSTRACT ............................... 1

I. INTRODUCTION . . . . . . . . . . . . . . . . . . . 1

II. AUTOMATIC CELL CYCLING SYSTEM . . . . . . . . . . . . . . . . . . 2

A. Cycle Control. . . . . . . . . . . . . . . . . 4

B. Limit Control. . . . . . . . . . . . . . . . . 4

C. Manual Control . . . . . . . . . . . . . . . 5

D. Timing Circuits. . . . . . . . . . . . . . . . 5

E. Power Control. . . . . . . . . . . . . . . . 6

III. DATA DISPLAY AND RECORDING . . . . . . . . . . . . . . . 6

A. Recorder ..................... . 6

B. Digital Readout. . . . . . . . . . . . . . . 6

C. Ce11 Capacity and Encrgy Measurements. . . . . . . . . . . 7

D. Miscellaneous Displays . . . . . . . . . . . . 7

IV. SUMMARY. . . . . . . . . . . . . . . . . . . 8 REFERENCES . . . . . . . . . . . . . . . . . . . . . 9

\section{LIST OF FIGURES}

No.

1. Block Diagram of Cell Cycling System. . . . . . . . . . . . . 2

2. Cell Cycling Control Console, Front View. . . . . . . . . . . 3

3. Cell Cycling Control Console, Rear View . . . . . . . . . . . 3

4. Typical Charge-Discharge Cycle for a Li-Al/FeS Cell . . . . . . 4

5. Typical Charge-Discharge Cycle for Li-Al/FeS Cell Showing Open-Circuit Perinds. . . . . . . . . . . . . . . 5 
INSTRUMENTATION FOR AUTOMATIC CYCLING OF
LITHIUM-ALUMINUM/IRON SULFIDE SECONDARY CELLS

by

W. F, O1sen and M. A. Slawecki

\section{ABSTRACT}

In the development of lithium-aluminum/iron sulfide secondary cells at Argonne National Laboratory, an instrumentation system was necessary to automatically operate experimental cells over extended periods of time. The system described in this report provides the capability for control of cell cycling and recording of data without the need for constant attendance by research personnel. In these tests electrical performance, power, energy storage capacity cyclelife and cell lifetimes are determined by repetitive charging and discharging of the cells.

\section{INTRODUCTION}

Electrically rechargeable, high-temperature lithium-aluminum/iron sulfide ( $\mathrm{FeS}$ or $\mathrm{FeS}_{2}$ ) cells of high specific energy are being developed at Argonne National Laboratory (ANL) for use in large batteries for bulk energy storage in electric utility systems. I Similar cells, but with higher specific power, are also being developed for use as electric vehicle batteries. ${ }^{2}$

In the development of these cells, cycling systems were necessary to automatically operate experimental cells over extended periods of time. In these tests, electrical performance, power, energy storage capacity, cyclelife, and cell lifetime must be determined by repetitive charging and discharging of the cells. By the use of automatic cyclers, round-the-clock operation of the cells is possible; the time required for operating personnel to perform individual cell tests is reduced by a factor of three and the personnel are thus free to perform other jobs such as cell fabrication and analysis of cell performance.

During the early stages of cell development when various geometries and materials were being tested, cells were relatively short-lived. At this time, the need for totally automatic cycling equipment was not great, and simple systems consisting of constant voltage power supplies, power resistors, and recorders were used. As optimum cell designs and materials were found, the cells were, of necessity, scaled up to handle greater amounts of current. Tests on the larger cells required aulumatic cyclers to determine whether or not the scaling-up introduced variables that changed the performance of cell components from values established in bench-scale tests. When automatic cyclers were introduced into the testing program, their value to researchers were immediately seen, and various sizes and types of units were needed to operate cells of different sizes and designs. In addition, those involved in the cell program found through experience with the cyclers that their utility would be enhanced by the incorporation of other functions into the 
system. This report describes the present cycler design, which includes all the additional features required to miximize the information gained during cell testing.

\section{AUTOMATIC CELL CYCLING SYSTEM}

The automatic cell cycling system consists of three separate sections: cycle-control, data display and recording, and power control. A block diagram of the system, in use at the present time, is shown in Fig. 1. Each of these sections is electrically connected as shown. The system can

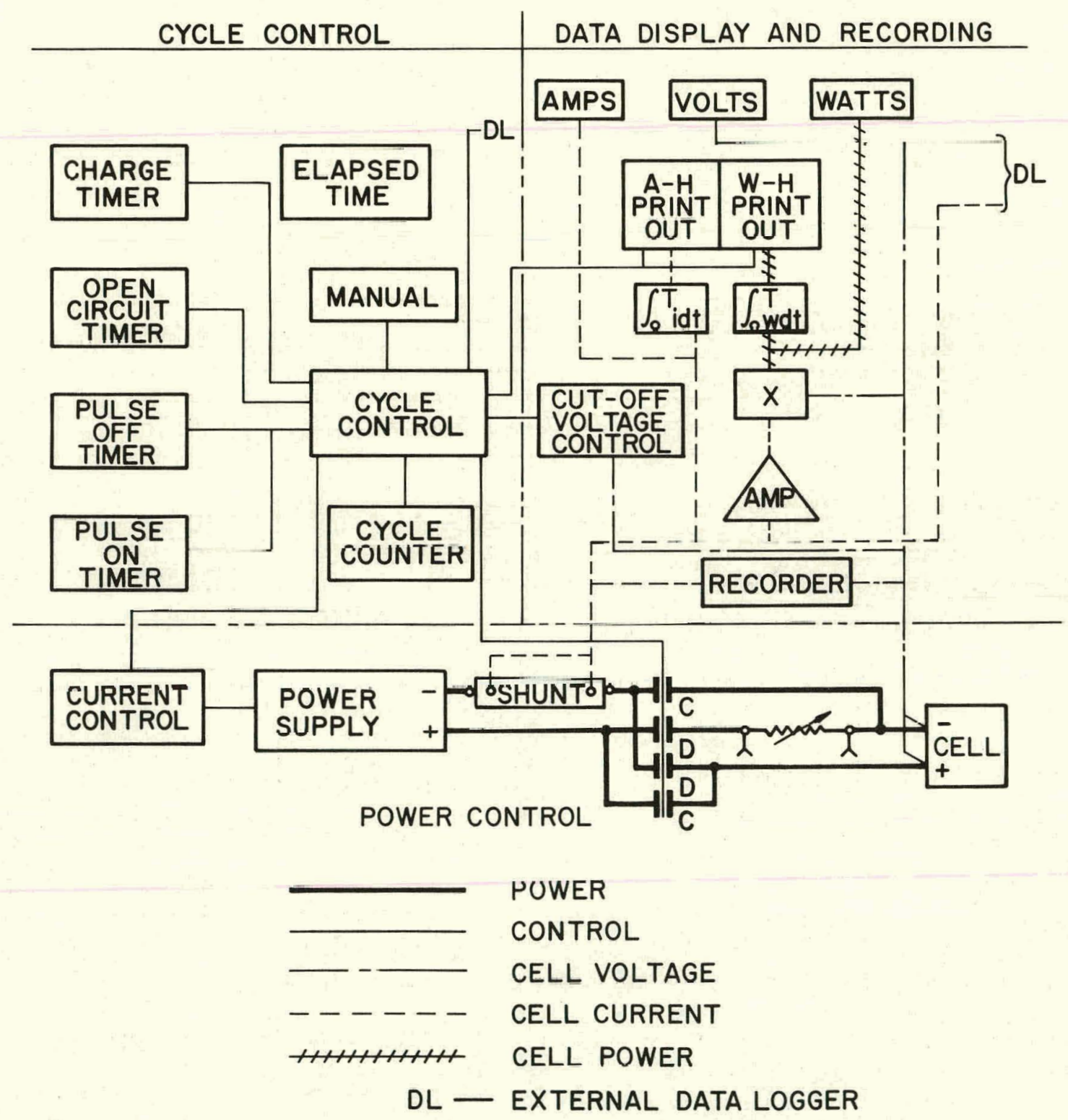

Fig. 1. Block Diagram of Cell Cycling System 
be operated automatically by the closed loop between cell voltage control and the power supply or manually in an open loop system. Figures 2 and 3 are photographs of the front and rear views of the cycler console. Cell charge or discharge is controlled in any one of three ways: cycle or automatic control, limit control, and manual control.

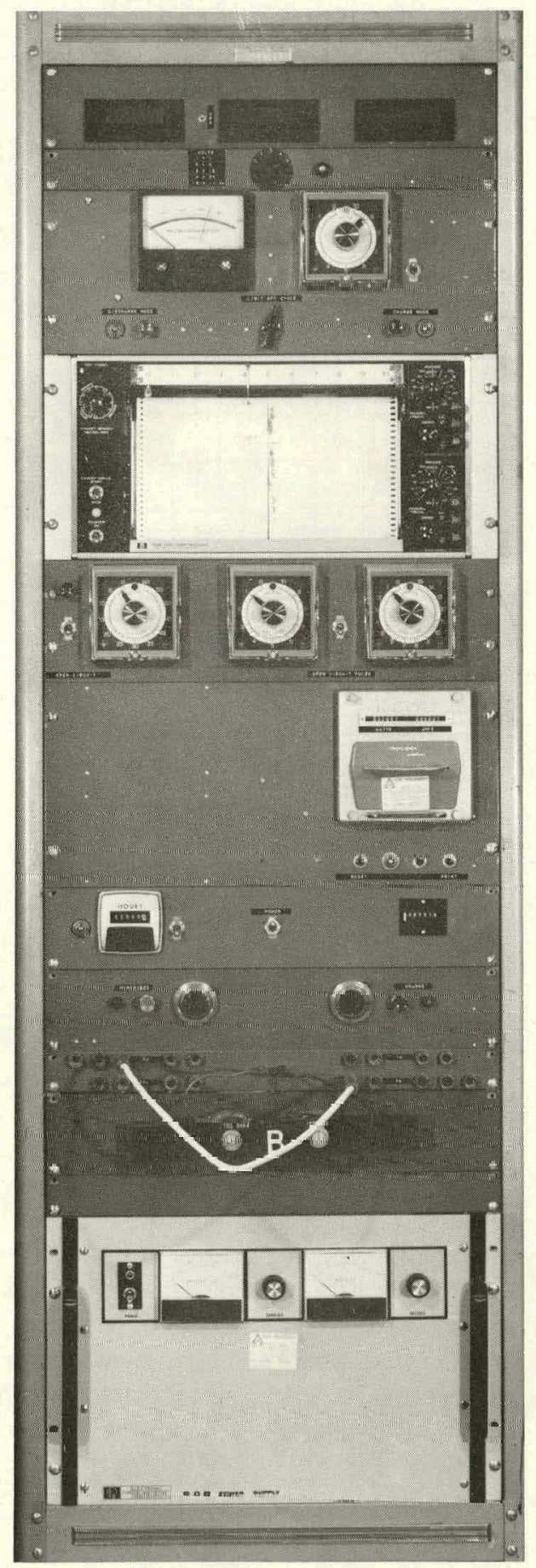

Fig. 2. Ce11 Cycling Control Console, Front View. ANL Neg. No. $308-76-120$

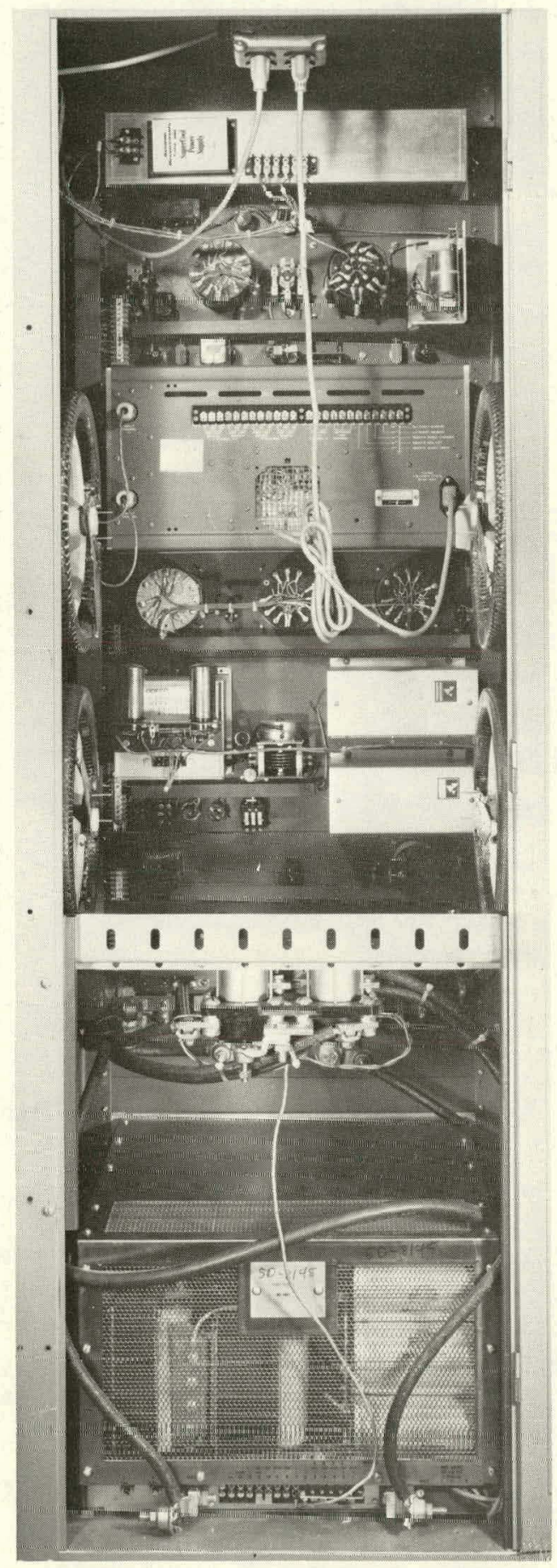

Fig. 3. Ce11 Cycling Control Consule, Rear View. ANL Neg. No. 308-76-118 


\section{A. Cycle Contro1}

Under cycle or automatic control, the cell is alternately switched from charge to discharge, or discharge to charge, whenever cell voltage exceeds the charge cutoff voltage $\left(\mathrm{V}_{\mathrm{cco}}\right)$ or drops below the discharge cutoff voltage $\left(\mathrm{V}_{\mathrm{dco}}\right)$ as sensed by a double-set-point, solid-state meter-controller. The ranges provided by the meter-controller are $1,5,10,50$ and $+1.25 \mathrm{~V}$. Under normal single-cell operation, the $5-\mathrm{V}$ range is utilized with $\bar{a}$ voltage resolution better than $0.1 \mathrm{~V}$. The $+1.25 \mathrm{~V}$ range is only used in the electrochemical formation of lithium-aluminum alloy. The higher voltage ranges are used for tests involving multiple series connected cells (batteries). Figure 4 shows a typical charge-discharge cycle for a Li-Al/FeS cell. Actual settings for $V_{\text {cco }}$ and $V_{d c o}$ may vary depending on materials of construction of the cell

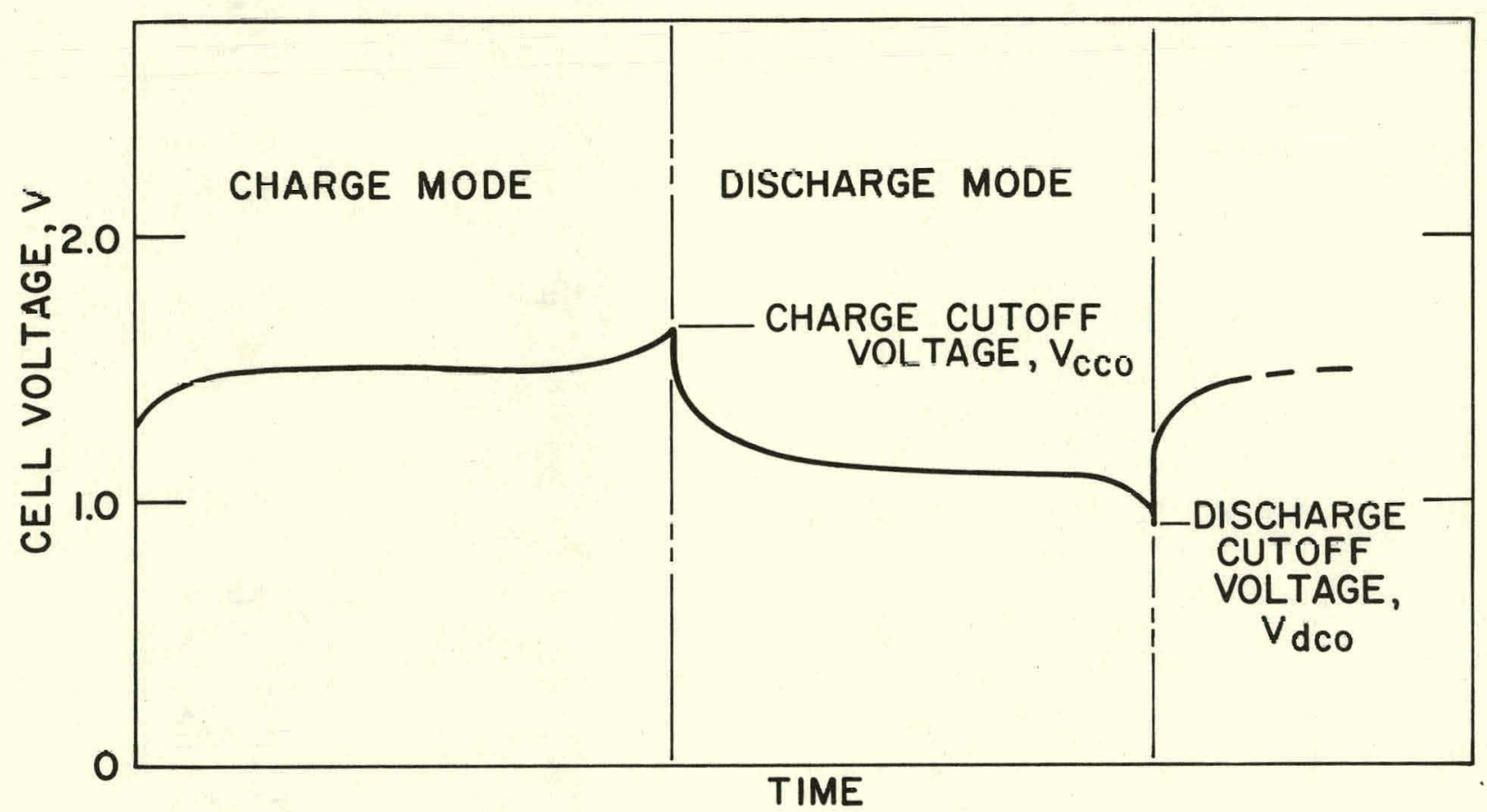

Fig. 4. Typical Charge-Discharge Cycle for a Li-Al/FeS Cell

electrodes. The choice of charge and discharge cut-off voltages is extremely critical in the operation of the $\mathrm{Li}-\mathrm{Al} / \mathrm{FeS}_{\mathrm{X}}$ cells because irreversible chemical reactions occur when these voltages are above or below the respective cutott levels. Optimum $\mathrm{V}_{\mathrm{cco}}$ and $\mathrm{V}_{\mathrm{d} c o}$ levels are still being sought for both the $\mathrm{FeS}_{2}$ and $\mathrm{FeS}$ systems and those shown in the figure are not necessarily optimum for FeS cells.

B. Limit Contro1

Limit control allows a cell to operate through a charge or discharge cycle until $\mathrm{V}_{\mathrm{cco}}$ or $\mathrm{V}_{\mathrm{dco}}$ is reached at which time the cell is placed in open circuit and remains in this condition until manually reset. A selector switch, which also acts as the reset switch for limit control, provides the 
choice between automatic and limit control. When the selector switch is in the off position, the cell is in the open-circuit condition.

\section{Manual Control}

The charge or discharge modes can be manually selected while the system is in automatic or limt control. Once placed in either mode, the automatic or limit control will complete the cycle in the selected mode.

\section{Timing Circuits}

Four timers are provided for various control options that experimenters find useful in cell testing. The charge time places a cell on charge for a fixed period of time. The selector switch must be in the "cycle" position, and the timer must be turned on manually for this option. The charge period will be determined by the preset charge time or by the charge cutoff voltage, whichever occurs first. The cycle then proceeds as before but with the charge timer controlling charge mode times. This function is required for very low charge rates or for constant-voltage charging where the steep rise to $V_{\text {cco }}$ is not present; the function is also used when work other than cell cycling is being done, $i . e .$, for other electrochemical experiments related to. cell work.

The open-circuit timer places the cell on open circuit for a set time period immediately after a charge or discharge cycle (see Fig. 5). This option is provided to allow the cell diffusional overvoltage to decay after a charge cycle or to rise after a discharge cycle, to the cell open circuit voltage. (This timer must be energized manually for operation.) A momentary contact switch is also provided to place the cell on open circuit manually at any time during charge or discharge.

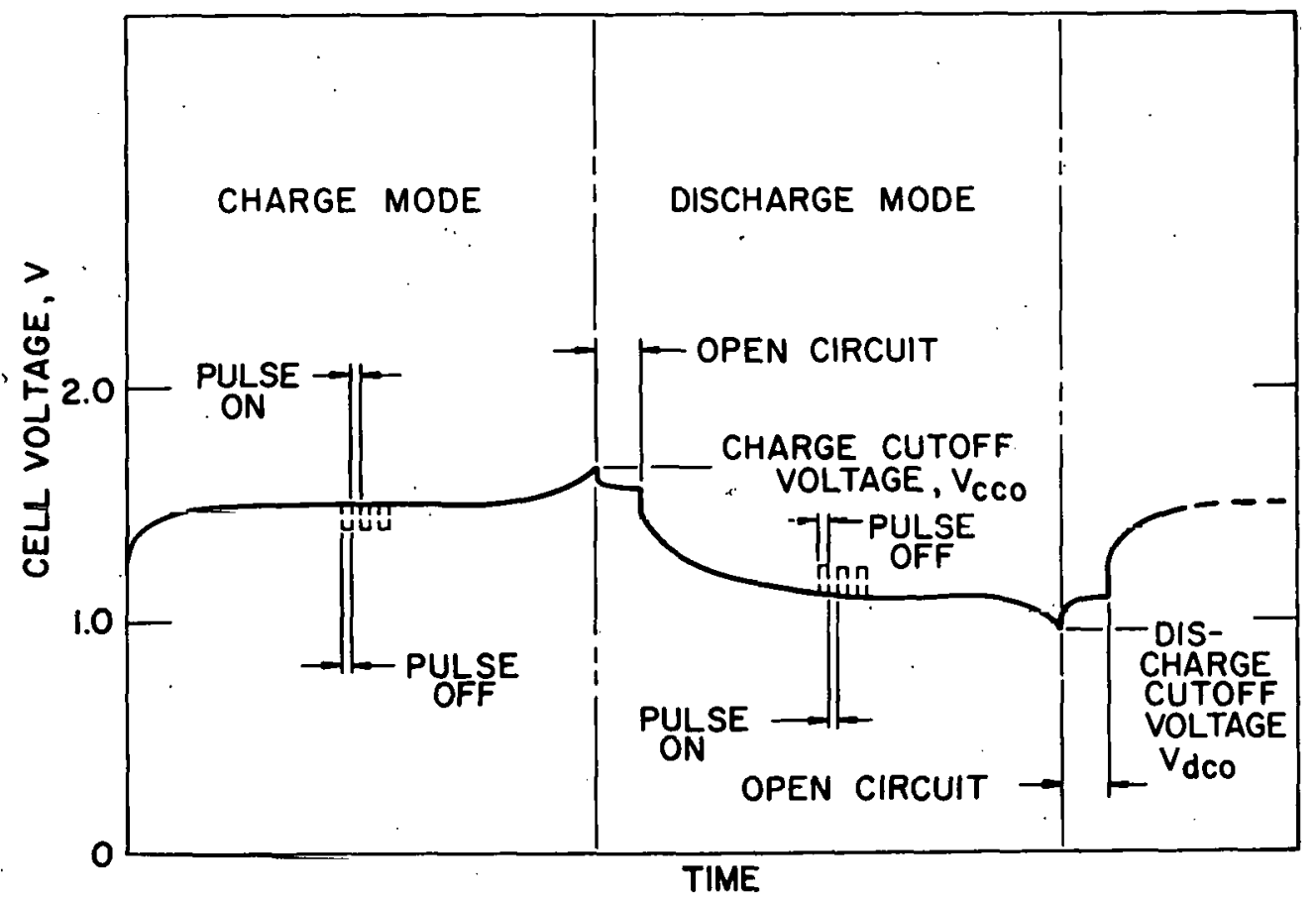

Fi.g. 5. Typical Charge-Discharge Cycle for Li-Al/FeS Cell Showing Open-Circuit. Periods 
Two additional timers are provided for repetitive open-circuit pulses during the charge or discharge modes. The open-circuit or "off" timer sets the open-circuit time interval required while the "on" timer determines the time interval between the open-circuit pulses. This feature allows the resistance overvoltage of the cell to be measured during the charge or discharge mode of operation, thereby providing a check of cell resistance and of possible changes in cell characteristics. The timers are energized: manually for operation.

\section{E. Power Contro1}

Cell operation during charge and discharge can be controlled in either a constant-current or constant-voltage mode. In either mode, current and voltage levels are maintained by controlling the output of a programmable, regulated power supply. Under constant-voltage control, the voltage level is set by the voltage control on the power supply, while current is controlled by variable power resistors in series with the cell; under this mode of control, the current level is limited by the rating of the resistors. Under constant-current control, the current is controlled by separate controls provided for charge and for discharge. Minimum discharge current level is controlled by a variable power resistor in series with the cell, if this is found to be necessary, for example, on very low current discharges, when the resistance in the circuit is not sufficient to maintain proper current control.

A constant voltage, current-1imit charge mode has been added to some of the cycling systems. In this mode the cell is charged initially up to the current limit and then as the cell voltage rises, the current decreases to a low level for a fully charged cell. It is felt that this mode of charging may be better for cell performance.

A large (200 A), reversing contactor with a mechanical interlock connects the cell to the power supply. The contactor is controlled from the circuits discussed earlier. The power supplies must be constant current-constant voltage units that can be remotely programmed.

\section{DATA DISPLAY AND RECORDING}

Varluus mellods are used Lo recurd and display the cell pardmeiers of voltage, current, power and capacity. Some provide a permanent record of cell performance while others provide instantaneous visual displays. The instruments that provide these capabilities, (shown schematically in Fig. 1) are described separately below.

\section{A. Recorder}

Cell voltage and current are recorded on a standard two-channel strip recorder that provides a record similar to that shown in Fig. 5. The recorder channels are both provided with selectable voltage ranges from $0.1 \mathrm{mV}$ to $100 \mathrm{~V}$ full scale, and also with variable zero controls. Resolutions as low as $0.05 \mathrm{~V}$ and $0.1 \mathrm{~A}$ are possible, depending upon the selected ranges and the current shunt output. Coded plug-in shunts of $100 \mathrm{mV}$ at $10 \mathrm{~A}, 100 \mathrm{mV}$ at $100 \mathrm{~A}$, and $50 \mathrm{mV}$ at $500 \mathrm{~A}$ are provided depending on the current range. The output from these shunts also drives the other display and recording devices in the system. 


\section{B. Digital Readout}

Cel1 voltage, current and power are displayed on four and one-half digit digital panel meters. Voltage is measured directly across the cell with a resolution as low as $1 \mathrm{mV}$. Cell current is read directly from the output of the shunts listed above with resolutions of $1 \mathrm{~mA}$ for the $10 \mathrm{~A}$ shunt, $10 \mathrm{~mA}$ for the $100 \mathrm{~A}$ shunt and $0.1 \mathrm{~A}$ for the $500 \mathrm{~A}$ shunt. Cel1 power is taken from the output of a multiplier circuit with resolutions of $0.01,0.1$ or $1 \mathrm{~W}$, depending on which shunt is used. A selector switch is provided to position the decimal point on the current and power digital panel meters, depending on the particular shunt used.

\section{Cell Capacity and Energy Measurements}

Measurements of cell capacity (in ampere-hours) and energy (in watt-hours) are required to accurately follow cell performance. Earlier methods of determining these quantities involved calculating the areas under the current and voltage curves of the recorder charts. This method was time-consuming and subject to errors in the calculations.

A two-channel printing impulse counter is now used to indicate amperehours and watt-hours directly. For ampere-hours, the millivolt signal from the current shunt is fed to an electronic integrator-totalizer. The totalizer provides a pulse output to drive one channel of the printing counter. Count rate is then directly proportional to current and is 1000,100 , or 10 counts per ampere-hour, depending on which shunt is used. Printout on paper tape occurs at the end of each discharge or charge cycle.

The second channel of the printing impulse counter prints out watt-hours. Power level is obtained by use of an analog multiplier circuit which uses cell voltage as one input and cell current as the other and provides an output in watts, calibrated as watts per volt. To minimize noise and drift characteristics of the multiplier circuit, the current signal in millivolts, which is taken from the shunts mentioned earlier, is amplified with a gain of 100 before being fed to the multiplier. The multiplier output drives the digital panel meter mentioned earlier and also serves as input to a second electronic integrator-totallzer whlch is separate from the unit used for ampere-hours. The totalizer provides a pulse output to drive the second channel of the impulse counter. Count rate is then directly proportional to power in watts and is 1000,100 , or 10 counts per watt-hour, depending on which current shunt is used. Again, printout on paper tape of total watt-hours in a charge or discharge cycle occurs at the end of each discharge or charge cycle.

\section{Miscellaneous Displays}

In addition to the functions outlined, a cycle counter and elapsed-time meter is provided on the console. The number of charge and discharge cycles are monitored by the cycle counter, which receives its signal from the cycle control system. The counter can be manually reset. The elapsed-time meter. can be used, if required, by manually energizing the timer. It is not directly associated with the cycle-control equipment. 
When required, the data generated during a cell testing program can be sent to a remote data logger. There are no particular problems associated with this operation, but if data is to be taken at a particular time, e.g.' at the end of charge or discharge, a signal from the cycle-control system to the data logger is necessary. At present, this signal is simply a relay contact closure. Under normal conditions, the data logger will take data under its own control at some particular set time cycle.

\section{SUMMARY}

In response to the needs of an ongoing program at ANL to develop rechargeable batteries, an automatic cell cycling system has been designed. This system provides the capability. for control of ceil cycling and recording of data without the need for constant attendance by research personnel. Thus, the cycling equipment has saved countless man-hours. The system also has a high degree of flexibility. Not only does the cycling equipment provide automatic cell operation under a number of modes of conlrul, but it can be used for other, related cell tests. The design of the cycler units has gradually been modified to provide the additional data on cell performance that were needed by experimenters. Moreover, the newer units have been built with sufficient capacity to cycle multiple-cell systems (batteries), and will be needed in future tests of full-size battery systems.

The cycling system described here is primarily under electromechanical control. This type of control was chosen because of the shorter design time required and the ready availability of parts. An effort is presently under way to design all solid-state cyclers for use in lifetime tests of the many cells being fabricated by industrial firms (an integral part of the ANL battery program). These cyclers will provide almost all the control functions described here, except that all data accumulation will be performed by a remote data logger. The solid-state units will be of modular torm so that a cycling system of requisite capacity can be easily provided for different sized cell and battery systems. 


\section{REFERENCES}

1. W. J. Walsh et al., "Development of Prototype Lithium/Sulfur Cells for Application to Load-Leveling Devices in Electric Utilities," Proc. 9th Intersociety Energy Conversion Engineering Conference, San Francisco, Calif... August 26-30, 1974, p. 911 (1974).

2. E. C. Gay et al., "The Development of Lithium/Sulfur Cells for Application to Electric Automobiles." Proc. 9th Intersociety Energy Conversion Engineering Conference, San Francisco, Calif., August 26-30, 1974, p. $862(1974)$. 
Internal:

M. V. Nevitt

R. V. Laney

P. R. Fields

S. A. Davis

B. R. T. Frost

G. T. Garvey

D. C. Price

K. E. Anderson

J. D. Arntzen

J. Barghusen

L. Burtholme

J. E. Battles

E. C. Berrill

C. A. Boquist

L. Burris

F. A. Cafasso

A. A. Chilenskas

T. Curvei'

P. Cunninghàm

D. Day

J. Dorsey

J. G. Eberhart

R. Elliott

W. R. Frost

E. C. Gay

F. Hornstra

A. A. Jonke

R. W. Kessie

G. M. Kesser (2)
V. M. Kolba

W. Kremsner

M. L. Kyle

W. W. Lark

S. Lawroski

C. A. Luartes

R. F. Malecha

A. E. Martin

F. J. Martino

C. A. Melendres

A. Melton

W. E. Millei

F. Mrazek

K. M. Myles

I'. Ulszaninski

P. A. Nelson (100)

E. G. Pewitt

E. R. Proud

S. Preto

G. Redding

M. F. Roche

L. E. Ross

J. Royal

W. W. Schertz

J. L. Settle.

H. Shimotake

J. A. Smaga

R. K. Steunenberg

C. A. Swoboda

A. D. Tevebaugh
W. D. Tuohig

Z. Tomczuk

D. R. Vissers

S. Vogler

W. J. Walsh

D. S. Webster

I. O. Winsch

S. E. Wood

N. P. Yao

S. A. Zivi

P. Eshman

J. E. A. Grane

J. L. Hamilton

J. Mathers

G. J. Benssteiil

K. G. Carroll

P. A. Eident

T n Kaun

J. E. Kincinas

K. Kinoshita

Z. Nagy

K. A. Reed

M. A. Slawecki

C. Sy

J. Williams

A. B. Krisciunas

ANL Contract Copy

ANL Libraries (5)

TIS Files (6)

\section{External:}

ERDA-TIC, for distribution per UC-94c (180)

Chief, Chicago Patent Group

V. Hummel, ERDA-CH

President, Argonne Universities Association

Chemical Engineering Division Review Committee:

R. C. Axtmann, Princeton Univ.

R. E. Balzhiser, Electric Power Research Institute

J. T. Banchero, Univ. Notre Dame

D. L. Douglas, Gould Inc.

P. W. Gilles, Univ. Kansas

R. I. Newman, Allied-General Nuclear Services

G. M. Rosenblatt, Pennsylvania State Univ.

J. G. Ahlen, Illinois Legislative Council, Springfield

J. N. Anand, Dow Chemical Co., Walnut Creek, Calif.

F. Anson, California Inst. Technology

P. Auh, Brookhaven National Laboratory

B. S. Baker, Energy Research Corp. 
H. Balzan, Tennessee Valley Authority

K. F. Barber, Div. Transportation Energy Conservation, USERDA

H. J. Barger, Jr., U. S. Army MERDC, Fort Belvoir

T. R. Beck, Electrochemical Technology Corp., Seattle

J. A. Belding, Div. Conservation Research \& Technology, USERDA

M. Benedict, Massachusetts Institute of Technology

D. N. Bennion, Univ. California, Los Angeles

J. Birk, Electric Power Research Inst.

J. Braunstein, Oak Ridge National Laboratory

M. Breiter, GE Research \& Development Center

J. O. Brittain, Northwestern U.

R. Brodd, Parma Technical Center, Union Carbide Corp.

J. J. Brogan, Div. Transportation Energy Conservation, USERDA

E. Brooman, Battelle Memorial Institute, Columbus

D. M. Bush, Sandia Laboratories

E. Buzzelli, Westinghouse Electric Corp., Pittsburgh

E. J. Cairns, General Motors Research Lab., Warren, Mich.

E. Carr, Eagle-Picher Industries, Joplin

P. Carr, Energy Development Associates, Madison Heights, Mich.

Chloride Systems (U. S. A.) Inc., North Haven, Conn.

C. Christenson, Gould Inc.

M. Cohen, Univ. of Chicago

A. R. Cook, Int'l Lead Zinc Research Organization, Inc., New York City

D. R. Craig, Hooker Chemical Corp.

G. Cramer, Southern California Edison, Rosemead

W. Dippold, Div. Transportation Energy Conservation, USERDA

J. Dunning, General Motors Research Lab., Warren, Mich.

P. Eggers, Battelle Memorial Institute, Columbus

R. P. Epple, Div. Physical Research, USERDA

J. H. B. George, Arthur D. Little, Inc.

J. Giner, Tyco Labs., Inc., Waltham, Mass.

C. Goddard, Div. Conservation Research and Technology, USERDA

G. Goodman, Globe-Union, Inc., Milwaukee

H. Grady, Foote Mineral Co., Exton, Pa.

S. Gratch, Birmingham, Mich.

D. Gregory, Institute of Gas Technology, Chicago

N. Gupta, Ford Motor Co.

N. Hackerman, Rice U.

G. Hagey, Div. of Energy Storage Systems, USERDA

R. Hamilton, Carborundum Co., Niagara Falls

W. Hassenzahl, Los Alamos Scientific Laboratory

L. A. Heredy, Atomics International

B. Higgins, Eagle-Picher Industries, Joplin

R. Hudson, Eagle-Picher Industries, Joplin

J. R. Huff, U. S. Army Mobility Equipment R\&D Center, Fort Belvoir

R. A. Huggins, Stanford U.

R. A. Huse, Public Service Electric \& Gas Co., Newark, N. J.

S. D. James, U. S. Naval Surface Weapons Center (3)

M. A. Jansen, Allegheny Power Service Corp. Greensburgh, Pa.

G. Janz, Rensselaer Polytechnic Inst.

H. Jensen, C\&D Batteries, Plymouth Meeting, Pa.

F. Kalhammer, Electric Power Research Institute

K. Kinsman, Ford Motor Co.

R. Kirk, Div. Conservation Research \& Technology, USERDA

K. W. Klunder, Div. of Energy Storage Systems, USERDA 
J. Lagowski, Detroit Edison Utility Co.

J. J. Lander, Air Force Aero Propulsion Lab., Wright-Patterson AFB

A. Landgrebe, Div. of Energy Storage Systems, USERDA (6)

C. E. Larson, Bethesda, Md.

S. H. Law, Northeast Utilities, Hartford, Conn.

H. Leribaux, Texas A\&M U.

D. Linden, U. S. Army Electronics Command, Fort Monmouth, N. J.

R. Llewellyn, Indiana State U.

P. S. Lykoudis, Purdue Univ.

J. McKeown, Office of Program Administration, USERDA

C. McMurty, Carborundum Co., Niagara Falls

R. McRae, ILC Technology, Sunnyvale, Calif.

D. Meighan, C. \& D. Batteries, Plymouth Meeting, Pa.

R. Minck, Ford Motor Co.

F. Moore, Div. of Energy Storage Systems, USERDA

G. Murray, Detroit Edison Utility Co.

E. Nicholson, Esso Research \& Engineering Corporate Res. Lab., Linden, N. J.

C. Pax, Div. Transportation Energy Conservation, USERDA

G. F. Pezdirtz, Div. of Energy Storage Systems, USERDA

R. Rightmire, Standard Oil of Ohio, Cleveland

R. Rizzo, Globe-Union Inc., Milwaukee

N. Rosenberg, Transportation Systems Center, Cambridge, Mass.

N. W. Rosenblatt, E. I. duPont de Nemours \& Co., Wilmington

R. Rubischko, Gould Inc.

A. Salkind, ESB Inc., Yardley, Pa.

G. Scharbach, American Motors General Corp., Wayne, Mich.

T. Schneider, Public Service Electric \& Gas Co., Newark, N. J.

R. I. Schoen, National Science Foundation

J. R. Schorr, Battelle Memorial Institute, Columbus

D. R. Schramm, Public Service Electric \& Gas Co., Newark, N. J.

H. J. Schwartz, NASA Lewis Research Center

J. R. Selman, Illinois Institute of Technology

A. I. Snow, Atlantic Richfield Co., Harvey, Ill.

S. Srinivasan, Brookhaven National Laboratory

D. Stakem, Catalyst Research Corp., Baltimore

E. Steeve, Commonwealth Edison Co., Chicago

R. H. Strange II, National Science Foundation

R. L. Strombotne, U. S. Dept. Transportation, Washington

S. Sudar, Atomics International

R. H. Swoyer, Pennsylvania Power and Light Co., Allentown

F. Tepper, Catalyst Research Corp., Baltimore

L. Thaller, NASA Lewis Research Center

G. M. Thur, Div. Transportation Energy Conservation, USERDA

C. W. Tobias, U. California, Berkeley

L. Topper, National Science Foundation

J. Vanderryn, Office of Intern. R\&D Programs, USERDA

J. V. Vinciguerra, Eagle-Picher Industries, Joplin

R. D. Walker, Jr., U. Florida

C. O. Wanvig, Jr., Globe Union, Inc., Milwaukee

S. A. Weiner, Ford Motor Co.

J. Werth, ESB Inc., Yardley, Pa.

C. Wienlein, Globe-Union Inc., Milwaukee

F. Will, General Electric R\&D Center, Schenectady

J. Withrow, Chrysler Corp., Detroit

W. L. Wonell, U. of California, Berkeley 
S. Wood, La Grange Park, Ill.

T. Wydeven, NASA Ames Research Center

O. Zimmerman, Portland General Electric Co., Portland, Ore.

M. Zlotnick, Div. Conservation Research and Technology, USERDA

Chloride Technical Limited, Manchester, England

E. Aiello, U. of Chicago

W. J. Argersinger, Jr., U. of Kansas

J. T. Banchero, U. of Notre Dame

K. J. Bell, Oklahoma State U.

R. Blanco, Oak Ridge Nat. Lab.

C. F. Bonilla, Columbia U.

W. Brandt, U. of Wisconsin-Milwaukee

A. E. Dukler, U. of Houston

W. J. Frea, Michigan Tech. U.

C. D. Harrington, Douglas United Nuclear, Inc.

J. E. Linehan, Marquette U.

Maine Univ., Prof. in charge of Chem. Engr. Lib.

Marquette U., Dept. of Chemistry

Michigan Tech. U., Library

G. Murphy, Iowa State U.

E. A. Peretti, U. of Notre Dame

G. W. Preckshot, Engr. U. of Missouri

H. Rosson, U. of Kansas

C. Sanathanan, U. of Illinois-Chicago Circle

A. Sesonske, Purdue U.

USERDA, Director, Div. of Safeguards and Security

B. W. Wilkinson, Michigan State U.

Comision Nacional de Energia Atomica, Library, Argentina

J. A. Sabato, Com. Nac. de Energia Atomica, Buenos Aires, Argentina

C. H. Cheng, Nat'l Tsing Hua Univ., China

National Radiological Protection Board, Library, Harwell, England

L. Kemmerich, Ges. für Kernforschung, Karlsruhe, Germany

F. Weigel, Inst. für Anorganische Chemie der U. Munich, Germany

N. Saratchandran, Bhabha Atomic Research Centre, Bombay, India

K. Fujimiya, U. of Tokyo, Japan

Japan Atomic Energy Research Inst., Tokai-mura, Japan

K. Matsuda, Inst. of Physical \& Chemical Res., Yamato-machi, Japan

Sang-Soo Lee, Korea Advanced Institute of Science, Korea

Korean Atomic Energy Research Institute, Korea

Ragnar Nordberg, Sahlgren's Hospital, Göteborg, Sweden 